\title{
Urban planning facing to dispersion in the traditional huertas of Region de Murcia
}

\author{
Alfonso Bernal Gallegoํ, Pedro J. Sánchez Balsalobre ${ }^{2}$, Fernando M. García Martín ${ }^{3, *}$, Marcos Ros Sempere ${ }^{4}$ and \\ María José Silvente Martínezs ${ }^{5}$
}

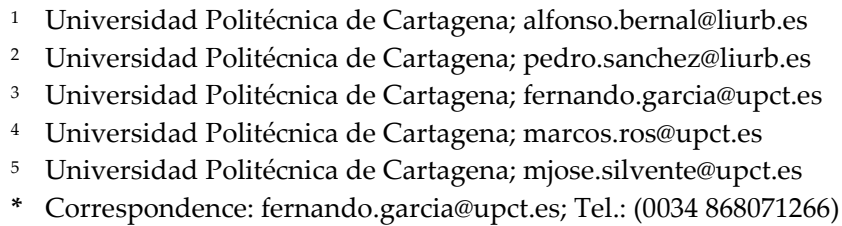

Citation: Bernal, A.; Sanchez, P.J.; Garcia, F.; Ros, M.; Silvente, M.J., 2022, Urban planning facing to dispersion in the traditional huertas of Region de Murcia. SUPTM 2022 conference proceedings sciforum- 054506 . https://doi.org/10.31428/10317/10495

Publisher's Note: UPCT and Sciforum stays neutral with regard to jurisdictional claims in published maps and institutional affiliations.

Copyright: (c) 2022 by the authors. Submitted for possible open access publication under the terms and conditions of the Creative Commons Attribution (CC BY) license (https://creativecommons.org/license s/by/4.0/).

\begin{abstract}
Adapt urban planning to areas where process of urban dispersion has occur is difficult. In this work, is assessed the response of the land law in Región de Murcia (Spain) to the sprawl of the peri-urban agriculatural areas (PUA Huertas).
\end{abstract}

Keywords: sprawl, land law, periurban, agroecology

\section{Introduction.}

The historical peri-urban agricultural areas of Huerta (PUA Huertas) along the Segura and Guadalentín Rivers in Murcia an Alicante are experimenting a process of sprawl since mid-20th century. At that period, a growing amount of scattered construction started to be build. This process has put in risk their agricultural, cultural and landscape values. At the same time, it has been a challenge for urban planning, traditionally aimed to the developing of new urban planned areas. However, in these areas, planning has had great difficulties to respond to this unplanned and extended sprawl process over a large area.

To face this process, the land law from Region of Murcia of 2001 included specific categories of land, beyond the traditional division in Spain among urban, developable and non-developable land. This work evaluates the response that the application of this law has had to order the dispersion in these agricultural territories. The intensity of the transformations in several cities of the orchards of the Segura and Guadalentín rivers is quantified, analysing the problem of the response given by urban planning.

The followed method uses geographic information systems, historical orthophotos and cadastral products to quantify the intensity of dispersion and assess the compliance of the determinations included in the urban planning.

The results confirm the inability of the urban planning measures adopted to stop the sprawl and to achieve a regularization of urban supplies in those areas where the process has formed unplanned build agglomerations. The comparison of different municipalities allows obtaining a vision of various types of urban response, which is especially interesting to propose alternatives to the future challenge of ordering these 'rururban' environments with urban planning.

\section{Study area.}

In Spain are several PUA Huertas, which are landscapes of small agricultural plots emerged thanks to the soil fertility and efficient distribution of the scares water resources. These crops areas are intimately linked to traditional urban settlements. The Dobris Report [1] state these Huertas as one of the thirteen European landscapes, highlighting their 
importance in heritage and cultural identity but also their singularity, because there are 1

only six of this landscapes in the European Mediterranean basin.

In Murcia and Alicante (at southeast Spain) PUA Huertas are an extended landscape over more than 80.000 ha along the Guadalentín and Segura Rivers. Different water channels follow one another along the valleys, allowing the irrigation in a mostly semiarid climate [2]. In between this extensive agricultural territory are a large number of urban nuclei of different sizes (the largest area Lorca, Murcia, Orihuela and Elche, but hundreds of small settlements can be found), becoming one of the largest peri-urbanization areas in the entire Mediterranean.

The urban-rural balance has been altering continuously in this area for more than 1000 years, dominating the rural component until the middle of the last century. From the 50s, two important phenomena break the status quo, inclining it towards the urban [3].

On the one hand, urban areas has grown at an unprecedented rate, both in the large nuclei and in the small settlements. This is a phenomenon similar to other Spanish cities at the time. First is due to migratory movements from the countryside to the city and later to the improvement of the economy.

On the other hand, there was also an increase in scattered constructions in the agricultural fabric [4]. Initially, it is due to the inability of cities to create houses for the entire population coming from other rural areas, but later to a trend chosen by the population that seeks a quality environment where build isolated houses.

\section{Land law and urban planning response to dispersion in the PUA Huertas of the Región de Murcia.}

The first land law of the Región de Murcia was approved in 2001, including two specific categories for traditional huertas: 'special urban land' and 'special developable land'. According with Spanish common law, rights and duties of landowners are different in each category.

The 'special urban land' included "linear settlements along roads, with relatively dense aggrupation of buildings (residential and other uses), endowed with complete urban facilities or with the possibility of being completed". The 'special developable land', for its part, included the lands of huertas "with existing settlement with peculiar characteristics, partial urbanization and special environmental surroundings where improvement actions can be implemented".

These categories were included in the adaptations to new land law of the urban planning of the municipalities in the period 2004-2007. In accordance with the law, the regulation of the building process in the huertas is made in two times in both categories:

- As lands with incomplete facilities, Special Urban Adequacy Plans (PEAU) must be elaborate to allow undertaking the urban transformation that completes the urbanization and determines the buildable areas in an integral way. A maximum floor space index of $0,25 \mathrm{~m}^{2} / \mathrm{m}^{2}$ is allowed in the areas of each special plan.

- Until the approval of PEAU, transitory regulations are established in the municipal urban planning (PGOU) in which the building conditions are indicate generally to all the plots that meet certain conditions, but without an overall planning. In this case, a maximum floor space index is defined for each plot.

\section{Method.}

The method followed analyses the degree of compliance with the determinations imposed by the general planning in four fragments of the Region of Murcia, the huertas of Lorca, Mula, Molina de Segura-Alguazas-Las Torres de Cotillas and Murcia.

For each fragment, the cadastral information and the historical orthophotographies have been used to identify the number of existing constructions in 2002 and 2017. These data make it possible to evaluate the number of buildings built under the regulation of the land law. 
In a second step, the built-up area is measured 2002 and 2017. For this, continuous building density calculation techniques have been used in GIS [5]. These data make possible to evaluate the adequacy of the conditions that must meet the PEAU both to the initial and to the current situation.

\section{Results.}

As it can be seen in Table 1, in the period from 2002 to 2017, in all the fragments of PUA Huerta analysed in the Region of Murcia there is a notable increase in the constructions over the traditional agricultural landscapes, with an average of $18.6 \%$ of new built area. Up to almost 7,000 new plots and 1,500,000 $\mathrm{m} 2$ were built in this period in these huertas. These data, by themselves, show the ineffectiveness of the current regulation in slowing down the dispersal process.

Table 1. Built plots and built area in 2002 and 2017 in the 4 fragments of PUA Huertas studied.

\begin{tabular}{|c|c|c|c|}
\hline Title 1 & & 2002 & 2017 \\
\hline \multirow{2}{*}{ Lorca } & Built plots & 5.077 & 6.895 \\
\hline & Built area & $3.420 .784 \mathrm{~m} 2$ & $3.943 .573 \mathrm{~m} 2$ \\
\hline \multirow{2}{*}{ Mula } & Built plots & 346 & 510 \\
\hline & Built area & $60.189 \mathrm{~m} 2$ & $67.204 \mathrm{~m} 2$ \\
\hline \multirow{2}{*}{ Molina de Segura } & Built plots & 2.464 & 3.830 \\
\hline & Built area & $336.875 \mathrm{~m} 2$ & 450.823 \\
\hline \multirow{2}{*}{ Murcia } & Built plots & 10.717 & 14.315 \\
\hline & Built area & 3.880 .248 & 4.665 .398 \\
\hline
\end{tabular}

In addition, the results show that there are large areas of these huertas that currently have a higher built-up area index than that allowed for the PEAU in the land law. For example, in the case of Lorca, although there is only $0.8 \%$ of the total area that has exceeded the limit, there is $22.2 \%$ of land that is above $65 \%$ of the permitted buildable area.

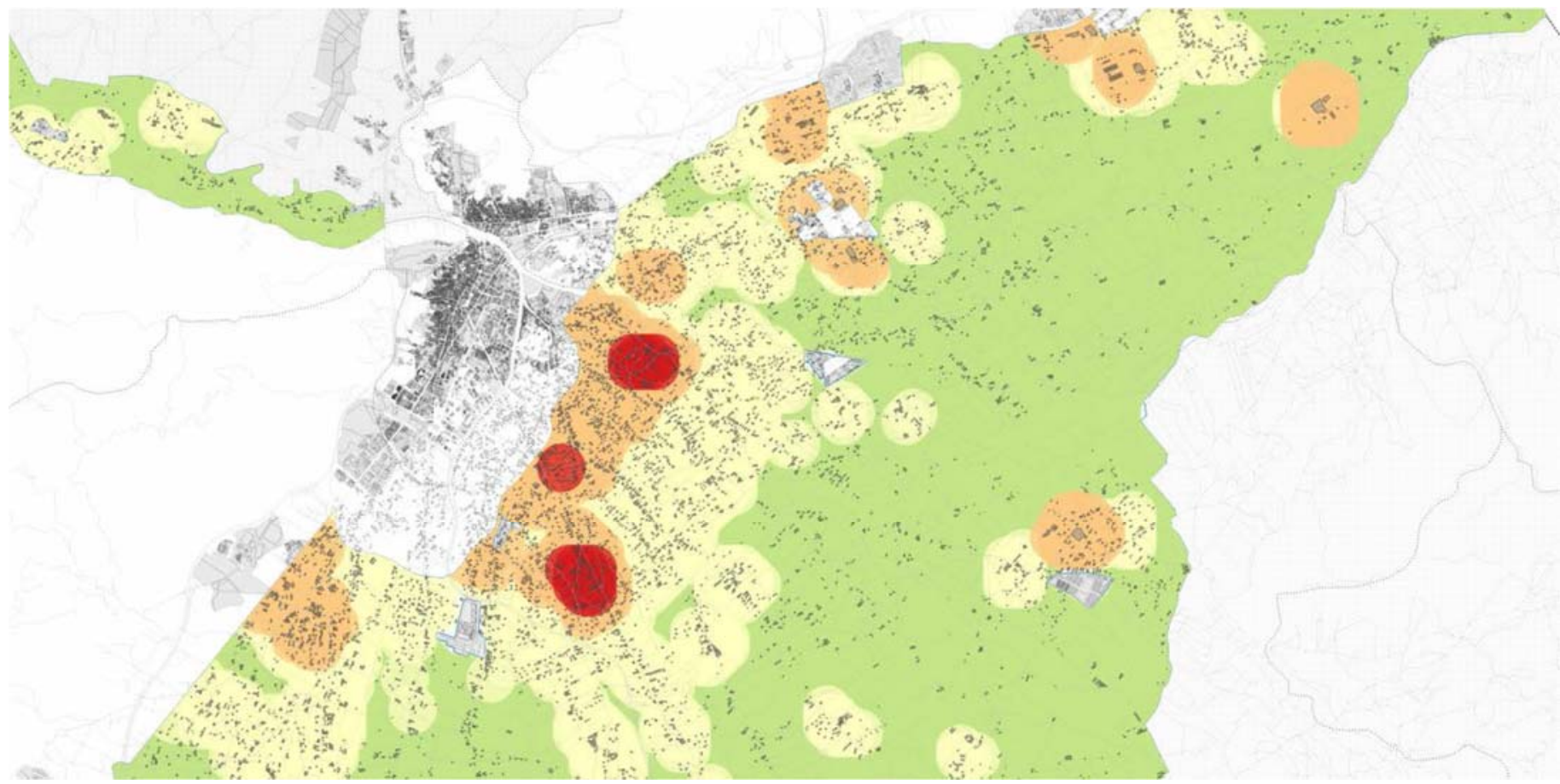

Figure 1. Saturation of the 'special developable land' in the huerta de Lorca. 
In the case of Murcia, currently $25.05 \%$ of the 'special urban land' has a built-up area 1 over that allowed by the land law, while another $44.58 \%$ is over the $50 \%$ of the allowed. It also stands out that already in $200220.17 \%$ of the surface exceeded the maximum and another $42.98 \%$ was above $50 \%$.

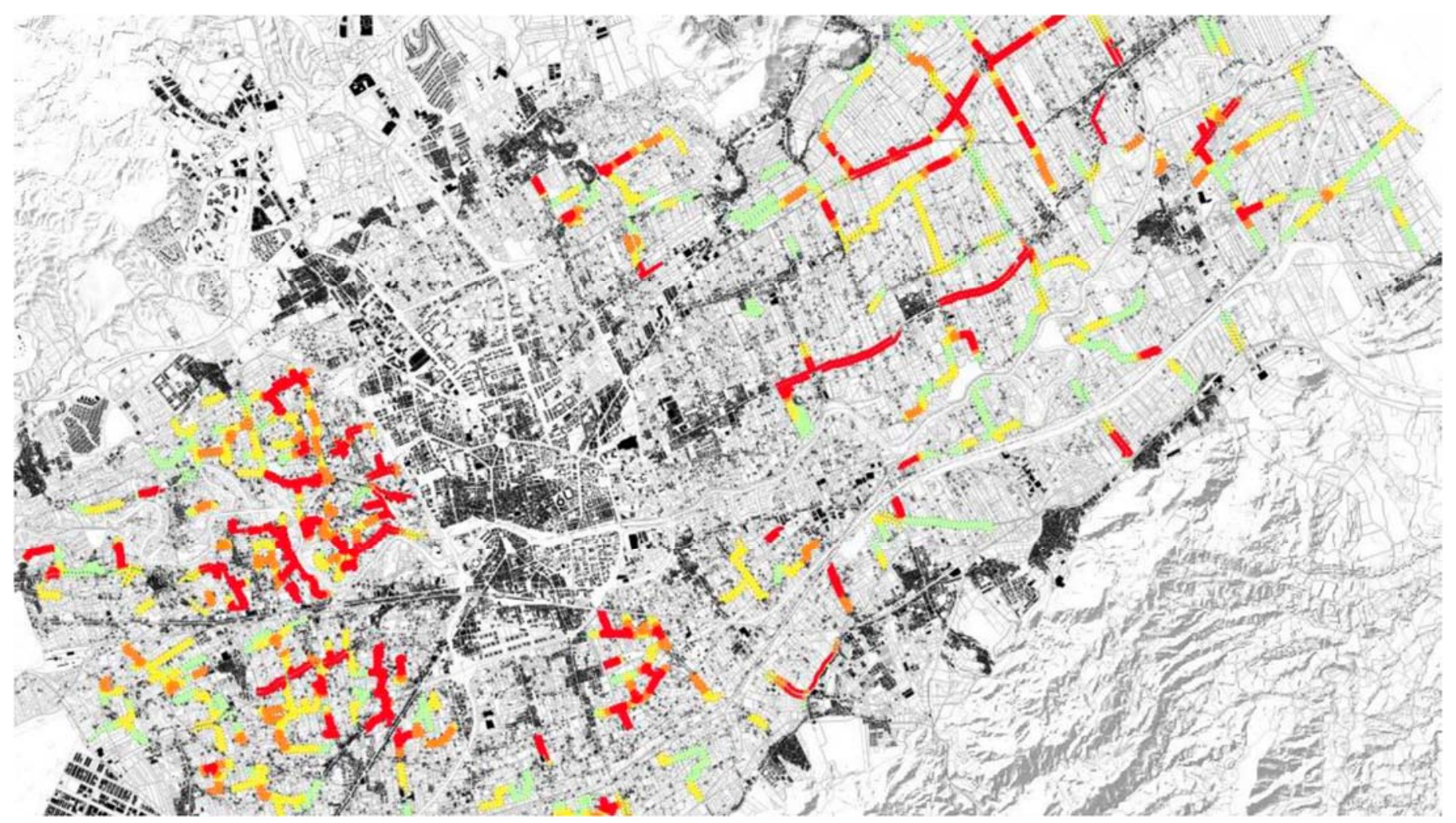

Figure 2. Saturation of the 'special urban land' in the Huerta de Murcia.

\section{Conclusions.}

This research has identified the ineffectiveness of the current land law in the Región de Murcia to stop the dispersion process and has highlighted the difficulties that the concentration of unplanned dispersal areas are to urban planning.

Although the work is focused on fragments of the PUA Huerta of the Region de Murcia, the challenge of ordering and conditioning the informal city and the sprawl city is common to other areas (for example, the recent attempts in Andalusia to regulate informal settlements). Urban planning must adopt effective measures to stop these processes, not only due to the need to make sustainable use of the territory, but also due to the difficulties that the subsequent regulation of these processes has.

Funding: This research was done in projects funded by the municipalities of Murcia, Mula, Molina de Segura and Lorca.

Conflicts of Interest: "The authors declare no conflict of interest."

\section{References}

1. European Environment Agency. (1998). Medio ambiente en Europa. El informe Dobris.

2. Calvo García-Tornel, F. (1982). Continuidad y cambio en la Huerta de Murcia. Murcia: Academia Alfonso X el Sabio.

3. Ros Sempere, M., \& García Martín, F. M. (2016). Cinco palmos 1929-2015. Transformación de usos del suelo en la Huerta de Murcia. Murcia: CRAI Biblioteca - Universidad Politécnica de Cartagena.

4. Mata Olmo, R., \& Fernández Muñoz, S. (2004). La Huerta de Murcia: Landscape Guidelines for a Peri-urban Territory. Landscape Research \& Landscape Research Extra, 29(4), 385-397. https://doi.org/https://doi.org/10.1080/0142639042000289028

5. García Martín, F. M. (2020). SIG y los análisis morfológicos territoriales y urbanos. In SIG revolution. Ordenación del territorio, urbanismo y paisaje (pp. 145-162). Madrid: Editorial Síntesis. 